\title{
Similarity and distinctions organizationally-technological schemes of recycling of industrial and automobile catalysts Kirichenko A. ${ }^{1}$, Seryogin A. ${ }^{2}$ \\ Сходство и различия организационно-технологических схем переработки промышленных и автомобильных катализаторов Кириченко А. С. ${ }^{1}$, Серегин А. Н. ${ }^{2}$
}

\author{
${ }^{1}$ Кириченко Андрей Сергеевич / Kirichenko Andrey - научный сотрудник; \\ ${ }^{2}$ Серегин Александр Николаевич / Seryogin Aleхаnder - доцент, кандидат технических наук, Ph.D., руководитель, \\ Центр ферросплавов и техногенного сырья, \\ Центральный научно-исследовательский институт черной металлургии им. И. П. Бардина, г. Москва
}

\begin{abstract}
Аннотация: в статье анализируются организационно-технологические схемы рециклинга промыциленных и автомобильных платиноидосодержащих катализаторов. Изложены преимущества двухстадийного проиесса для переработки катализаторов транспорта.

Abstract: in article organizational and technological schemes of a recycling industrial and automobile platinoid catalysts are analyzed. Benefits of two-stage process to conversion of catalysts of transport are stated.
\end{abstract}

Ключевые слова: организация реияиклинга, платиноиды, катализатор.

Keywords: organization of recycling, platinoids, catalyst.

Многие химические процессы протекают в присутствии катализаторов - более $90 \%$ всех химических превращений. В большинстве реакций наибольшей каталитической активностью обладают металлы платиновой группы (МПГ) - платина, палладий, родий, относящиеся к числу драгоценных металлов. Повышение температуры в рабочей зоне, как правило, способствует росту активности катализатора. Однако для этих целей в каталитическую массу приходится добавлять рений - довольно дорогостоящий редкий металл, придающий жаропрочность сплавам и покрытиям ( $\mathrm{Re}$-металл, не входит в МПГ) [1].

Для производства новых катализаторов применяют ряд методов - осаждение из растворов, пропитку, смешение и сплавление с последующим выщелачиванием неактивной части и другие. При работе из-за примесей во входном потоке реагента происходит отравление катализатора, его каталитическая активность падает и он требует замены [2]. Наиболее стабильны промышленные катализаторы, некоторые из которых эксплуатируются более 10 лет [3].

Катализаторы выхлопных газов современных автомобилей служат для доокисления экологически вредных компонентов выхлопа до менее токсичных газов и по статистике требуют замены каждые 100 тыс. км пробега [4]. В среднем 15-17\% всех используемых в стране платиносодержащих катализаторов ежегодно заменяются новыми. Все драгоценные металлы дороги и редки в природе, что определяет потребность их рециклинга и вовлечения во вторичный оборот [5].

В России доминирующие позиции по потреблению МПГ занимают нефтехимические катализаторы риформинга, использование их растет по мере роста экологических требований к топливу. Сегодня на 35 российских заводах загружено порядка 3400 т катализаторов риформинга. Ежегодная потребность в обновлении оценивается в 300-400 т. Процесс каталитического риформирования применяется для повышения октанового числа бензинов и изготовления ароматических углеводородов (бензола, толуола, ксилола). Выпуск новых катализаторов налажен на АО «Промышленные катализаторы» и АО «Ангарский завод катализаторов и органического синтеза». С 2005 г. на АО «Промышленные катализаторы» освоено производство эффективного катализатора ПР-71 (загружен на установках ОАО «Саратовский НПЗ», ЗАО «РНПК», ООО «Линос») [3].

Вторую позицию по масштабам применения МПГ в промышленности занимают катализаторы гидрокрекинга. Гидрокрекинг - это процесс производства качественных керосиновых и дизельных дистиллятов, а также вакуумного газойля путем крекинга углеводородов из исходного сырья в присутствии водорода. Одновременно с крекингом происходит очистка продукта от серы. В 2000-х годах введены мощности на предприятиях в Перми (2004), Рязани (2005), Ярославле (2005) и Уфе (2005). ОАО «Роснефть» в ближайшие годы планирует ввести еще 9 установок на своих заводах.

Катализаторы с МПГ применяются также в системах газоочистки на ряде предприятий органической химии. Для алюмопалладиевых катализаторов газоочистки характерна высокая активность. Однако дороговизна, возрастающий дефицит МПГ, делает проблематичным широкое применение их в газоочистке промпредприятий. Более дешевы катализаторы на основе оксидов $\mathrm{Mn}, \mathrm{Co}, \mathrm{Cu}, \mathrm{Zn}$.

Таможенные правила стран Таможенного Союза запрещают в настоящее время ввоз новой автотранспортной техники ниже 4 экологического класса [6]. Хотя Россия по введению жестких экологических норм на транспорте отстает от стран ЕС, США и Японии, в соответствии с Киотским протоколом, в среднесрочной перспективе намечается лишь ужесточение действующих национальных 
норм [7]. А в перспективе расширение требований на специализированную внедорожную (сельскохозяйственную, лесную, строительную, грузоподъемную, коммунальную) технику и средства смежных видов транспорта с приводом от автотранспортных двигателей внутреннего сгорания (ДВС) [8].

Конструктивно экологический класс ЕВРО-5 и выше достигается лишь при установке на газовом выпускном тракте ДВС специальных систем, того или иного типа, окисления выхлопных газов, снижающих вредные выбросы в атмосферу. Наиболее распространены в мировой практике и экологически эффективны автокатализаторы, содержащие МПГ [9]. Преимущественно они представляют собой керамический алюмосиликатный блок, с нанесенным покрытием платиноидов или их солей, заключенный в нержавеющий стальной корпус, через каналы которого пропускаются выхлопные газы [10]. За срок службы автомобиля катализаторы требуют замены несколько раз. Кроме того, блоки растрескиваются и преждевременно выходят из строя, если при работе в них попадает вода через выхлопную трубу или же при сильных ударах корпуса об ухабы дороги. Для России это весьма важный аспект. Количество ежегодно образующихся в стране отработанных катализаторов автотранспорта нарастает лавинообразно. В мире, по статистическим данным, основным сырьевым источником вторичных МПГ становятся отработанные катализаторы транспорта, их мировая переработка достигает 40 млн единиц в год [11].

Экспорт лома и отходов черных и цветных металлов достиг максимума в 2001-2005 годах [12]. Затем началось его снижение из-за сокращения ресурсной базы [13]. Ввиду этого актуален поиск резервов извлечения металлов путем вовлечения в переработку новых видов сырьевых ресурсов [14], расширения внедрения новых технологий [15].

Организационно технологическая схема рециклинга промышленных катализаторов отработана многолетней практикой. Изготовители промышленных катализаторов обязаны снабдить его паспортом изделия, в котором указывается общая масса, содержание драгоценных и цветных металлов. Аналогичная информация обязательна и при поставке по импорту. При демонтаже катализатора производится на основе эмпирических данных оценка улёта драгметалла с реагентом (нефтью, отходящими газами и пр.) и оценка остатка МПГ в катализаторе.

Затем завод заключает с аффинажным предприятием договор на переработку катализатора на согласованных сторонами коммерческих условиях. Осуществляется пробоотбор выгруженного из установки катализатора и отправка проб на химический анализ в лабораторию, а также фиксируется общая масса отправляемого каталитического вещества.

По прибытии катализатора на аффинажное производство его лаборатория производит свои анализы общего содержания МПГ, рения и др. металлов в партии. Берутся контрольные пробы. Стороны производят расчеты за взаимно согласованное количество драгметалла в партии [16]. В случае расхождения оценки массы драгметалла продавцом и покупателем в катализаторе контрольные пробы передаются для независимого анализа. А при несогласии сторон с результатами экспертизы - дело передается в арбитраж.

Масса промышленного катализатора риформинга может достигнуть порядка 1000 тонн, а весь процесс переработки длится от нескольких месяцев до полугода. Химический анализ отобранных проб осуществляется методами аналитической химии, что предполагает продолжительное (до недели) растворение проб в сильных кислотах [17].

Отмеченная организационно-технологическая схема рециклинга промкатализаторов оказалась малоэффективной для рециклинга катализаторов транспорта. Ввиду этого в России количество извлекаемых из автокатализаторов вторичных МПГ мало. Предприятия ломозаготовки цветных металлов России в должной мере не вовлечены в этот процесс и в лучшем случае выступают лишь как посредники. Трудности заключаются в малом количестве МПГ в одном изделии, малой концентрации и большом разбросе концентраций МПГ в алюмосиликатной каталитической массе, отсутствии дешевых приборов для экспресс-анализа [9].

Относительно благополучна ситуация с отработанными автокатализаторами иномарок, обслуживаемых на специализированных центрах ведущих мировых автопроизводителей. Такие отработанные катализаторы, с известным содержанием драгметалла и химсоставом покрытия, попадают в поле действия системы обслуживания автопроизводителя, накапливаются и централизовано вывозятся из страны для извлечения МПГ в ближайших центрах переработки. Этим же путем идет АвтоВАЗ, собирая на автоцентрах отработанные катализаторы, устанавливаемые на ряде своих моделей. Они укрупняются в партии однотипных изделий, с учетом заводской маркировки этих деталей. Однако, доля таких катализаторов в общем объеме мала.

Основная же масса этого сырья заготавливается в России от поддержанных иномарок, поступающих в страну с катализаторами самых различных типов и производителей, с неизвестным содержанием МПГ.

Из-за дороговизны нового катализатора легкового автомобиля (порядка 1000 долл. США), по истечении срока гарантии многие отечественные собственники автотранспорта (как частные лица, так и 
предприятия) меняют отработанные катализаторы на более дешевые универсальные по назначению модели, часто производства третьих стран и малоизвестных производителей, или на обычные глушители в автомастерских, где отработанные автокатализаторы частично оседают в запасниках, а частично продаются сборщикам цветного лома.

Далее предметом купли-продажи выступает цельный керамический блок отработанного катализатора, или масса каталитической его части (если он частично растрескался, раскрошился). Масса блока для легкового автомобиля порядка 1 кг, при суммарном содержании платиноидов - 1-3 грамма. Такой товар, обычно распакованный по полиэтиленовым мешкам, может храниться весьма долго, в ожидании выгодного покупателя. Нержавеющие корпуса же реализуются как лом нержавеющей стали [18].

Для полного излечения МПГ из сырья катализаторов и получения слитков вторичных драгметаллов, предприятиям системы ломозаготовки РФ необходимо иметь лицензию на аффинажное производство, что сложно и дорого для них. Однако, и аффинажные предприятия России пока не проявляют должного интереса к переработке автокатализаторов. Для них предпочтительны долговременные связи с промышленными поставщиками. Партии же отработанных автотранспортных каталитических блоков, которые могут продать заготовители цветных металлов или же непосредственно автомастерские представляют собой, как правило, разнородную массу изделий как по химсоставу керамического носителя, так и \% составу МПГ, содержащихся в каждом каталитическом элементе. Кроме того, для применения аффинажных технологий гидрометаллургического извлечения МПГ из массы сырья желательно, чтобы концентрация МПГ во входной партии достигала суммарно 6-8\%. Иначе происходит низкое использование уникального оборудования для получения вторичных драгметаллов.

Отсутствие данных о содержании драгметаллов в отдельном автокатализаторе и трудности экспрессанализа химсостава затрудняют куплю-продажу и денежные расчеты с первичными заготовителями.

В результате существенная доля блоков заготовляемых в стране отработанных катализаторов ДВС по бросовым ценам, и обычно серым схемам, запродается и уходит на переработку в ближайшие страны Запада, то есть ценные драгметаллы вывозятся за пределы страны. А нарушения в таможенной сфере наносят стране весомый экономический урон [19].

Для переработки катализаторов транспорта в современных условиях России рационально принять двухстадийный процесс. На первом этапе сбор, накопление и первичную переработку сырья возложить на предприятия по сбору и переработке вторичных цветных металлов с привлечением их сети приемных пунктов, а второй этап переработки - выполнять на аффинажном производстве.

На первом этапе осуществляется прием автокатализаторов от ломозаготовителей, разделка корпусов с оплатой за массу керамического блока с учетом типа катализатора. Быстрый качественный анализ на наличие в покрытии тех или иных МПГ, а также рения может быть выполнен переносным рентгенофлуоресцентный анализатором металлов, который по цене доступен ломозаготовителям [20]. Целесообразна также первичная сортировка каталитических блоков на: содержащие рений и без рения, от дизельных ДВС или же от бензиновых. После накопления товарной партии каталитические блоки перемалывают и перемешивают, берут пробы и отправляют их в стороннюю химлабораторию на анализ. Результаты анализа используют при назначении параметров технологического процесса 1-ого этапа, которым является металлургическая (дуговая, плазменная) плавка размолотого материала. На данном этапе МПГ концентрируются на подине печи. Получается богатый МПГ металл коллектор и побочный шлак. Для интенсификации процесса осаждения в плавку добавляют коллектор. Весомыми преимуществами обладает технология с использованием железа, как металл - коллектора, из-за его дешевизны. Керамический каркас катализаторов, отделенный от металлического корпуса в среднем содержит $1 \%$ железа, что само по себе является достаточным для процесса осаждения. Для увеличения степени извлечения целесообразно брикетировать молотые катализаторы вместе с металл-коллектором на основе чугуна. Отобранную партию керамических блоков автокатализаторов размалывают, тщательно перемешивают, добавляют необходимое количество связующего и металл-коллектора, увлажняют и брикетируют, тем самым получая довольно однородный по химсоставу и содержанию драгметаллов полупродукт [21]. Выполненная в ЦНИИчермет им. И. П. Бардина серия плавок показала, что требуемый механизм перемешивания расплава достигается в печи постоянного тока. Данный способ позволяет получить степень извлечения более 99,5\% [22].

Полученная в результате электроплавки укрупненная товарная партия автокатализатора уже направляется на второй этап - аффинажное производство, для выделения рения, разделения МПГ и получения чистых вторичных металлов или их солей гидрометаллургическими технологиями. Взаиморасчеты между предприятием, первичным переработчиком, и аффинажным заводом выполняются уже по описанной ранее схеме на основе анализа проб за массу каждого из металлов в партии.

Для роста производства вторичных МПГ целесообразно расширенное внедрение двухстадийного процесса при переработке катализаторов ДВС автомобильного и смежных видов транспорта [23].

\section{Литература}


1. Кириченко А.С., Серегин А.Н., Алексахин А.В. Новые возможности развития мирового и отечественного производства рения // Техника и технология: новые перспективы развития, 2014. № XIII. C. 92-97.

2. Серегин A.Н., Кириченко A. С. Рециклинг ванадия из отработанных катализаторов // Вторичные металлы, 2008. № 4. С. 70.

3. Вахрушин A. Ю. Утилизация отработанных катализаторов риформинга нефти // Вторичные металлы, 2008. № 2. C. 70-71.

4. Серегин A. Н., Кириченко А. С. Рециклинг автомобильных катализаторов // Вторичные металлы. 2013. № 1. C. 44 .

5. Гагарский Э. А., Кириченко И. С. Концепция устойчивого развития и новые подходы в сфере рециклинга металлов и техногенного сырья // Вторичные металлы, 2013. № 3. С. 34.

6. Гагарский Э.А., Кириченко С. А., Кириченко А.С. Снижение выбросов двигателей внутреннего сгорания транспорта и повышение требований к катализаторам выхлопных газов и их рециклингу // Транспорт: наука, техника, управление, 2013. № 7. С. 22-25.

7. Гагарский Э. А., Кириченко А. С. Ужесточение экологических требований к автомобильным катализаторам и их утилизации // Бюллетень транспортной информации, 2013. № 4 (214). С. 003-007.

8. Кириченко A. С., Букин А. В., Алексахин А. В. Прогрессивные технологии и организационные схемы авторециклинга - утилизации строительной техники // Техника и технология: новые перспективы развития, 2014. № XV. С. 135-141.

9. Кириченко A. C. Актуальные проблемы рециклинга автомобильных катализаторов // Современные проблемы науки и образования, 2013. № 3. С. 43.

10. Кириченко А. С. Опыт переработки катализаторов на «ПЗЦМ-ВТОРМЕТ»// Вторичные металлы, 2013. № 2. C. 50.

11. Серегин A. Н., Кириченко А. С. Авторециклинг в московском регионе // Вторичные металлы. 2013. № 5. C. 41.

12. Кириченко С. А. География экспорта металлолома // Рынок вторичных металлов, 2001. № 6. С. 12-15.

13. Кириченко И. С., Бабаян П. Д. Тенденции экспорта лома черных металлов из РФ // Вторичные металлы, 2015. № 5-6. С. 50.

14. Кириченко И. С. Один из способов выхода из кризиса // Вторичные металлы, 2016. № 1. С. 10 - 14.

15. Серегин А.Н., Ермолов В.М., Степанян А. С., Арсентьев В.А. Технологии и оборудование для утилизации металлосодержащих отходов // Вторичные металлы, 2009. № 5. С. 48.

16. Кириченко A.C., Серегин A.Н., Антонов А. А. Развитие технологии и организация переработки платиноидосодержащих автомобильных и промышленных катализаторов // Вторичные металлы, 2015. № 5-6. С. 57-59.

17. Федюнина Н. Н., Кириченко А. С., Серёгина И. Ф., Волков А. И., Серёгин А. Н. О некоторых методах определения содержания металлов платиновой группы в отработанных автомобильных катализаторах и продуктах их переработки // Проблемы черной металлургии и материаловедения, 2014. № 1. С. 1.

18. Кириченко И. С., Алексахин А. В., Серегин А. Н. Особенности и тенденции рынка лома нержавеющих сталей // Молодой ученый, 2015. № 7. С. 148-153.

19. Кучин О. С. Усиление таможенного контроля за перемещением драгоценных металлов т драгоценных камней // Бизнес, менеджмент и право, 2010. № 1 (21). С. 125-131.

20. Серегин А. Н., Кириченко А. С. Определение платиновых металлов в отработанных автомобильных катализаторах // Актуальные проблемы гуманитарных и естественных наук, 2013. № 7-1. С. 67-71.

21. Кириченко A. C., Серегин A. Н. Способ переработки катализаторов, содержащих металлы платиновой группы на носителях из оксида алюминия. Патент РФ № 2553117 С2 // Изобретения. Полезные модели, 2015. № 16. С. 1-8.

22. Kirichenko A. S., Seregin A. N., Volkov A. I. Developing a technology for recycling automotive exhaust-gas catalysts // Metallurgist, 2014. T. 58. № 3-4. C. 250-255. DOI:10.1007/s11015-014-9897-z.

23. Кириченко С.А., Кириченко И. С. Утилизация локомотивов. Проблемы и зарубежный опыт // Вторичные металлы, 2012. № 6. С. 44. 